と比べて図 9 のように優れた伝熱特性を有する。このた め廃熱利用の反応器や, 発熱・吸熱反応を組み合わせて 熱回収を行うケミカルヒートポンプ用反応器としての利 用が期待される。

\section{6.これからの展望}

本研究室ではこれまでに図10に示すような種々の形 状の触媒を調製してきた。これらはすべて熱交換器型の 反応器を想定して調製したものである。今後, 圧力損失 が少ない, 熱効率の優れた反応器として種々のシステム に適用できると考えている。

(1995-2-6 受理)

\section{文献}

1) スコッチョアリオ, 亀山秀雄 ; 化学工学会第 59 年会, B306 (1994)

2 ）長沢 徹, 亀山秀雄; 化学工学会第59年会, B305（1994）

3 ) 寺井 聡, 亀山秀雄; 化学工学会第 26 秋季大会, p. 105 (1993)

4) 寺井 聡, 亀山秀雄 ; 化学工学会つくば大会, SB 111 (1994)

5 ) 村田 究, 龟山秀雄; 化学工学会第 26 秋季大会, p. 103 (1993)

\title{
小特集 “アノード酸化一製法，機能および応用”によせて
}

アノード酸化は, めっき・ドライプロセスと並び表 面処理技術の大きな柱の一つであり，本協会において あ, 投稿論文 - 口頭発表 - 研究会等々で数多く取り上 げられ，多くの関心が寄せられています。

古くは“アノード酸化＝アルマイト”という図式む ありましたが, 現在では使用される素材は, アルミニ ウム, マグネシウムそしてバルブ金属からシリコンへ と多岐にわたっています。さらに，利用方法について も, 下地素材を高機能化する耐食, 装飾などの従来型 の用途に加え，表面皮膜に機能を与える担持層的利用 方法から多孔質皮膜を分離膜として利用する方法, さ らには皮膜をネガ材料として他の材質の多孔質薄膜を 作製する方法など多種多様な拡がりを見せています。 本特集では，このアノード酸化に焦点をあて，現在 の研究開発の動向，各種材料の処理技術の現状及びト
ピックス的な応用例について, 各分野でのご専門の先 生方に執筆をお願い致しました。読者の皆様のお仕事 の一助となることを願っております。最後になりまし たが，本小特集のために貴重なお時間をお割き頂きま した諸先生方に厚く御礼申し上げます。

（堀口 誠)

〔本小特集企画委員〕

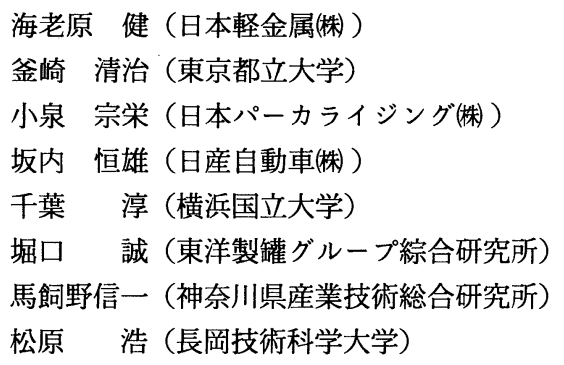

海老原 健（日本軽金属(株)

清治 (東京都立大学)

ジング(株)）

坂内 恒雄（日産自動車(株)

堀口誠（東洋製䧾グループ綜合研究所） 馬飼野信一（神奈川県産業技術総合研究所） 松原＼cjkstart浩（長岡技術科学大学） 